\title{
Hiv, amming og antiretrovirale medisiner
}

\author{
På hivkonferansen i Cape Town i juli 2009 ble det presentert tre store \\ kontrollerte kliniske studier med lovende resultater i kampen for \\ å redusere hiv-1-smitte fra mor til barn. Disse studiene dannet et viktig \\ grunnlag for de nye retningslinjene som ble lansert i november 2009. \\ Amming anbefales nå som det beste alternativet for mødre i fattige \\ land når det samtidig gis antiretrovirale medisiner. De slipper dermed \\ å velge mellom morsmelkerstatning, som gir økt dødelighetsrisiko, \\ og amming, som gir hiv-1-smitterisiko.
}

\author{
Ingunn Marie Stadskleiv Engebretsen \\ ingunn.engebretsen@cih.uib.no \\ Thorkild Tylleskär \\ Senter for internasjonal helse \\ Universitetet i Bergen \\ Årstadveien 21 \\ 5009 Bergen
}

Hvert år blir omtrent 420000 barn smittet av hiv-1. De fleste får smitten fra moren via svangerskap, fødsel eller amming. Mer enn to millioner barn lever med hiv-1, og årlig dør omtrent 300000 av aids. Hiv-1-positive mødre i lavinntektsland har stått overfor et enormt dilemma om hvorvidt de skal amme eller ikke (1). Dette dilemmaet er ikke til stede på samme måte i høyinntektsland. Retningslinjene i disse landene, forenklet gjengitt, er basert på optimal viral suppresjon under svangerskap og forløsning samt keisersnitt fremfor vaginal forløsning ved hiv-1-RNA på mer enn $50 \mathrm{kopier} / \mathrm{ml}$ ved uke 34-36 og morsmelkerstatning fremfor amming (2).

\section{Mors dilemma}

Det ene alternativet, å unngå amming, gir ingen risiko for postnatal hiv-1-smitte, men en betydelig tilleggsrisiko for alvorlige sykdommer som pneumoni og infeksiøs diaré, som svært ofte er ledsaget av underernæring. Dette gir igjen økt dødelighetsrisiko. Nylig viste en ikke-randomisert intervensjonsstudie fra Sørvest-Uganda at selv der mødrene fikk velge mellom fullamming eller gratis morsmelkerstatning, hadde barna som fikk morsmelkerstatning høyere dødelighetsrisiko (18\% versus $3 \%$ ) (3). Morsmelkerstatningsgruppen fikk opplæring i hygiene og oppfølging i hjemmet. De fleste hadde vann fra kran eller pumpe.

Amming gir spedbarna fordelene av morsmelk, men økt risiko for postnatal hiv1-smitte. Barn som blir hiv-1-smittet tidlig har en betydelig tilleggsrisiko for sykdom og død. Sørafrikanske forskere viste i 1999 at fullamming i seks måneder kunne redusere postnatal hivsmitte til samme nivå som ved morsmelkerstatning og at morsmelk sammen med annen føde ga høyest smitterisiko for hiv-1 (4). Store randomiserte studier i en rekke afrikanske land har senere bekreftet disse funnene $(5,6)$. Tidlig etter årtusenskiftet tenkte man at en kort fullammingsperiode ville gi en rekke fordeler for barnet samtidig som man reduserte den kumulative hiv-1-smitterisikoen som forlenget amming innebærer.

Dessverre var ammestopp etter fullamming i under seks måneder også et problematisk alternativ. I en randomisert studie fra Lusaka i Zambia ga man intervensjonsgruppen råd om ammestopp ved fire måneders alder, mens kontrollgruppen fortsatte å amme så lenge de ønsket. Hensikten var at barna skulle få fordelene ved morsmelkernæring, men forkortet risikoperiode for hiv-1-smitte. Intervensjonsgruppen fikk morsmelkerstatning, termos til kokt vann og barna fikk trening i å drikke av kopp, noe som er mer hygienisk enn tåteflaske. I begge studiearmene hadde $35 \%$ tilgang på komfyr og de fleste hentet vann fra offentlige kraner. Resultatene var nedslående. Av dem som ble hiv-1-smittet var dødeligheten mye høyere i intervensjonsgruppen enn kontrollgruppen ved 24 måneders alder ( $74 \%$ mot $55 \%, p=0,007)$. Den hiv-1-frie overlevelsen ved samme alder var ikke signifikant forskjellig i intervensjonsgruppen sammenliknet med kontrollgruppen (68\% $\operatorname{mot} 64 \%, p=0,13)(7)$.

\section{Detaljerte retningslinjer}

Uten noen intervensjon er den vertikale smitterisikoen blitt beskrevet fra $30 \%$ til $45 \%$ : 5-10\% i svangerskapet, $10-20 \%$ under fødselen og $10 \%-20 \%$ ved amming (8). Studier fra etter tusenårsskiftet har vist at antiretroviral medisinering (zidovudin) i svangerskapet og under fødselen og nevirapin til mor og barn henholdsvis under og like etter fødselen ga redusert smitterisiko både i svangerskapet og under fødselen $(9,10)$.

I 2006 kom de forrige retningslinjene for hvilke medisiner mor og spedbarn skulle få, avhengig av mors immunstatus (CD4-T-hjelpecellenivå), økonomi og tilgjengelighet på leveringsstedene (11). Siden slutten av 1990-årene har det også pågått utstrakt revisjon av hva slags råd mor skal få om spedbarnsmating. Morsmelkerstatning er hittil fra WHO blitt anbefalt kun der det er akseptabelt, trygt og et varig praktisk og økonomisk gjennomførbart alternativ. Fortolkningen av disse rådene har variert $i$ en rekke land og har fort til noe forvirring og intens debatt. Retningslinjene fra 2006 er i stor grad implementert i en rekke land, og det har vært en tung og langtrukket prosess mange steder.

\section{Nye behandlingsprinsipper ved amming og hiv}

De nyeste studiene innen postnatal vertikal hiv-1-smitte ble presentert ved hivkonferansen i Cape Town i juli 2009 (5th International AIDS Society (IAS) Conference on HIV Pathogenesis, Treatment and Prevention (12). De følger to prinsipper. Det ene er å gi kvinnen full antiretroviral behandling (HAART, Highly Active AntiRetroviral Treatment) under både svangerskap og ammeperiode selv om hun ikke trenger det for sin egen helses skyld. Det andre er å gi barnet peri- og posteksposisjonsprofylakse med et antiretroviralt medikament henholdsvis under ammeperioden og en periode etterpå. De to prinsippene er ikke blitt kombinert med samme medikamenter, da man har vært redd for blant annet toksiske doser av medisinene hos barnet.

To store intervensjonsstudier, SWENog PEPI-studiene $(13,14)$ fra 2008, ga lovende resultater ved bruk av perieksposisjonsprofylakse (nevirapin) til barnet $\mathrm{i}$ henholdsvis seks og 14 uker i ammeperioden. Noe av problemet med disse to studiene var at medisineringen ikke dekket hele ammeperioden.

Kesho Bora-studien fulgte det første prinsippet om å gi mor HAART-behandling under ammingen (15). Denne randomiserte 


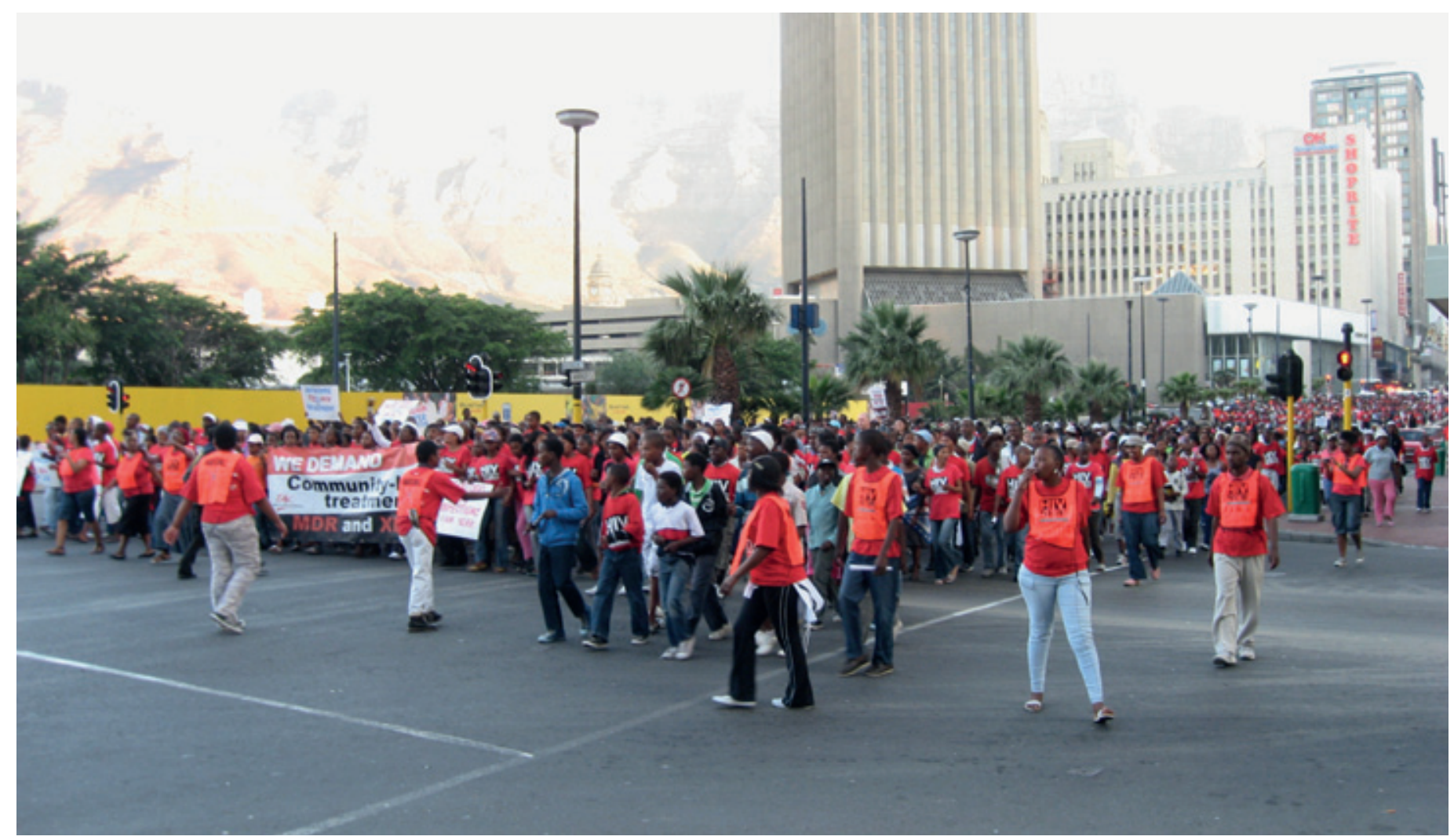

Sørafrikanske aktivister demonstrerer for å sikre forsyningene av hivmedisin under slagordet «Treatment is prevention» utenfor hivkonferansen arrangert av International AIDS Society i juli 2009. Foto Thorkild Tylleskär

kliniske studien ble utført i Burkina Faso, Kenya og Sør-Afrika fra 2005 til 2008 og inkluderte 824 hiv-1-positive mødre med CD4-nivå på 200-500 celler/ml. Intervensjonsgruppen fikk HAART-behandling bestående av zidovudin, lamivudin og lopinavir/ritonavir fra svangerskapsuke 28-36 og til maksimalt seks og en halv måned etter fødselen. Kontrollgruppen fikk standard antiretroviral behandling i svangerskapet og under fødselen med zidovudin og lamivudin fra uke 28-36 til fødsel samt en enkeltdose nevirapin under fødselen til kvinnen. Barnet fikk en enkeltdose nevirapin rett etter fødselen. Halvveis i studien fikk kontrollgruppen en uke forlenget behandling. Moren fikk zidovudin og lamivudin en uke etter fødselen og barnet fikk zidovudin i første leveuke. Kontrollgruppen fikk ellers ikke behandling under ammeperioden. Begge gruppene fikk opplæring om ammestopp ved seks måneders alder. I intervensjonsgruppen var totalt 5,6\% smittet, mot 9,3\% i kontrollarmen, ved 12 måneders alder.

I Mma Bana-studien fikk kvinnene HAART-behandling under svangerskapet og i ammeperioden (16). De ble randomisert til to ulike HAART-regimer som dekket samme periode. Studien ble utført i Botswana og inkluderte 560 kvinner med over 200 CD 4 celler $/ \mathrm{ml}$. Smitte under amming skjedde i liten grad - i denne studien ble bare to barn smittet i ammeperioden, og manglende gjennomføring av medisine- ringen ble identifisert som et problem hos disse to. Medisinene ble godt tolerert.

BAN-studien ble gjennomført i Malawi. Der sammenliknet man de to prinsippene «HAART til mor» og «profylakse til barnet» (17). For en ammeperiode på seks måneder og en måneds etterbehandling sammenliknet man tre studiearmer for 2367 inkluderte mor-barn-par. I den første var det HAART-behandling til mor, i den andre et antiretroviralt medikament (nevirapin) som profylakse til barnet, den tredje var en kontrollarm med Malawis standardbehandling under svangerskap og fødsel med noe ernæringsstøtte i tillegg. Den siste studiearmen ble stoppet før tiden etter råd fra studiens overvåkingskomité, da det var høy smitterisiko - 6,4\% - i denne armen. I studiearmen med HAART-behandling til mor var det totalt $3,0 \%$ smittede barn ved 28 ukers alder, mot $1,8 \%$ i studiearmen der barna ble gitt profylakse.

Det foreligger planer om å teste ut andre og mer effektive medisiner med lavere bivirkningsprofil og mindre risiko for utvikling av resistens, noe som er spesielt problematisk ved bruk av nevirapin som profylakse til barnet (18). I en åpen kohortstudie med brysternærte barn fra Tanzania ga lamivudin som perieksposisjonsprofylakse til barnet en smitterisiko ned mot $1 \%$ ved seks måneders alder (19). I en helt fersk oppfølgingsstudie fra samme studiegruppe var det tilsvarende gode resultater ved bruk av HAART-behandling hos mor (20).

\section{Nye retningslinjer}

De nye funnene om HAART-behandling til moren eller profylakse til barnet innebærer at retningslinjene fra 2009 i større grad enn tidligere fremmer amming som et trygt alternativ $(21,22)$. Tidligere anbefalinger om spedbarnsernæring er blitt vurdert som svært kompliserte å forholde seg til (23). De siste studiene har gitt håp om at hiv-1positive mødre også i fattige land kan slippe å stå i dilemmaet mellom morsmelkerstatning, som gir økt dødelighetsrisiko, eller amming, som gir hiv-1-smitterisiko. Dette er viktig, selv om det tidligere ble vist at fullamming reduserer hiv-1-smitte. Fullamming blir sjelden gjennomført optimalt hos alle, selv ikke med mye veiledning (24). I tillegg kan en rekke faktorer hos både mor og barn, som redusert brysthelse hos mor og oral-gastro-intestinal helse hos barnet, bidra til økt hiv-1-smitterisiko. Barn av hiv-1positive mødre kan da nyte godt av den helsebringende effekten av amming, og helsevesenet kan gi enhetlig ammeveiledning uavhengig av hiv-1-status. Det vil være en milepæl på veien for å redusere barnedødeligheten i henhold til FNs tusenårsmål nummer 4, da vi vet at fullamming i seks måneder i seg selv er det tiltaket som har størst potensial til å redusere barnedødeligheten (25).

\section{Gjennomførbart?}

Selv om studiene som er presentert her, har brakt stor optimisme i feltet rundt postnatal 
hiv-1-smitte, er det behov for nøye faglige vurderinger. Studiene er ikke i utgangspunktet sammenliknbare med henblikk på intervensjon, CD4-nivå, varighet av medisinering av kvinnen under svangerskapet og dermed viral suppresjon, ernæringsråd, oppfølging og monitorering av spedbarnsernæring, studieendepunkt og sosioøkonomisk kontekst (26).

Selv om kunnskapen øker, er det mange utfordringer igjen. Det er mange hivsmittede gravide som ikke har tilgang til selv de billigste og enkleste forebyggingsregimene som allerede finnes. Ifølge WHO fikk $33 \%$ av hivpositive gravide i middel- og lavinntektsland antiretrovirale medisiner for å redusere smitte til barnet i 2007, mot bare $10 \%$ i 2004 . Og bare $12 \%$ ble vurdert for hivbehandling for sin egen helses skyld (27).

De siste retningslinjene $(21,22)$ er radikale i rådgivningen om antiretroviral behandling og strekker seg kanskje forbi hva det per i dag finnes dokumentasjon for. Forfatterne sier selv flere steder at det er moderat til svakt datagrunnlag bak noen av anbefalingene. Samtidig er noen pragmatiske løsninger valgt, da man vet hvor uheldig det har vært de siste ti årene med vage og utydelige formuleringer. De siste retningslinjene legger også større vekt på helsepersonellets rådgivningsansvar enn på individets valg, i tillegg til at de promoterer integrering av forebygging og behandling av hiv-/aidsarbeidet i svangerskaps-, fødsels- og spedbarnsoppfølgingen i offentlig svangerskapsomsorg. I dag opererer ofte PMTCT-programmer (prevention of mother-to-child transmission) på siden av resten av helsevesenet. I mange afrikanske land har programmene uavhengig ekstern finansiering. Store logistiske utfordringer eksisterer $\mathrm{i}$ arbeidet med å øke tilgjengeligheten av programmene for gravide kvinner, både når det gjelder forsyninger, infrastruktur og på personellsiden. Implementerings- og evalueringsforskning er derfor viktig for å kunne velge gode og effektive programmer. Uansett må store anstrengelser og prioriteringer til for å forhindre hiv-1smitte av barn i fattige land.
Oppgitte interessekonflikter: Ingen

\section{Litteratur}

1. Tylleskar T. Mors vanskelige valg. Tidsskr Nor Lægeforen 2004; 124: 73-4.

2. Clumeck N, Pozniak A, Raffi F. European AIDS Clinical Society (EACS) guidelines for the clinical management and treatment of HIV-infected adults. HIV Med 2008; 9: 65-71.

3. Kagaayi J, Gray RH, Brahmbhatt $\mathrm{H}$ et al. Survival of infants born to HIV-positive mothers, by feeding modality, in Rakai, Uganda. PLoS ONE 2008; 3: e3877.

4. Coutsoudis A, Pillay K, Spooner E et al. Influence of infant-feeding patterns on early mother-to-child transmission of HIV-1 in Durban, South Africa: a prospective cohort study. South African Vitamin A Study Group. Lancet 1999; 354: 471-6.

5. Iliff PJ, Piwoz EG, Tavengwa NV et al. Early exclusive breastfeeding reduces the risk of postnatal HIV-1 transmission and increases HIV-free survival. AIDS 2005: 19: 699-708.

6. Coovadia HM, Rollins NC, Bland RM et al. Motherto-child transmission of HIV-1 infection during exclusive breastfeeding in the first 6 months of life: an intervention cohort study. Lancet 2007; 369: 1107-16.

7. Kuhn L, Aldrovandi GM, Sinkala M et al. Effects of early, abrupt weaning on HIV-free survival of children in Zambia. N Engl J Med 2008; 359 $130-41$

8. De Cock KM, Fowler MG, Mercier E et al. Prevention of mother-to-child HIV transmission in resource-poor countries: translating research into policy and practice. JAMA 2000; 283: 1175-82.

9. Efficacy of three short-course regimens of zidovudine and lamivudine in preventing early and late transmission of HIV-1 from mother to child in Tanzania, South Africa, and Uganda (Petra study): a randomised, double-blind, placebo-controlled trial. Lancet 2002; 359: 1178-86.

10. Jackson JB, Musoke P. Fleming T et al. Intrapartum and neonatal single-dose nevirapine compared with zidovudine for prevention of mother-tochild transmission of HIV-1 in Kampala, Uganda: 18-month follow-up of the HIVNET 012 randomised trial. Lancet 2003; 362: 859-68.

11. WHO. Programmes and projects. Mother-to-child transmission of HIV. Revisions to WHO guidelines for antiretroviral treatment of pregnant women and prevention of HIV infection in infants. www.who.int/hiv/topics/mtct/revisions/en/ index.html (15.2.2010)

12. 5th IAS Conference on HIV Pathogenesis, Treatment and Prevention 19-22 July 2009. www.ias2009.org/ (15.2.2010).

13. Bedri A, Gudetta B, Isehak A et al. Extended-dose nevirapine to 6 weeks of age for infants to prevent HIV transmission via breastfeeding in Ethiopia, India, and Uganda: an analysis of three randomised controlled trials. Lancet 2008; 372: 300-13.

14. Kumwenda NI, Hoover DR, Mofenson LM et al. Extended antiretroviral prophylaxis to reduce breast-milk HIV-1 transmission. N Engl J Med 2008; 359: 119-29.

15. de Vincenzi I. Kesho Bora Study Group. Triple-antiretroviral (ARV) prophylaxis during pregnancy and breastfeeding compared to short-ARV prophylaxis to prevent mother-to-child transmission of HIV-1 (MTCT): the Kesho Bora randomized controlled clinical trial in five sites in Burkina Faso, Kenya. Abstrakt. www.ias2009.org/pag/Abstracts.aspx? AID=3631 (15.2.2010)

16. Shapiro R, Hughes M, Ogwu A et al. The Mma Bana Study Team. A randomized trial comparing highly active antiretroviral therapy regimens for virologic efficacy and the prevention of mother-to-child HIV transmission among breastfeeding women in Botswana (The Mma Bana Study). Abstract. http://www.ias2009.org/pag/Abstracts.aspx?AID $=3821$ (15.2.2010).

17. Chasela C, Hudgens M, Jamieson D et al. Both maternal HAART and daily infant nevirapine (NVP) are effective in reducing HIV-1 transmission during breastfeeding in a randomized trial in Malawi: 28 week results of the Breastfeeding. Antiretroviral and Nutrition (BAN) Study. Abstrakt. www.ias2009.org/pag/Abstracts.aspx?AID=3751 (15.2.2010).

18. Musoke PM, Barlow-Mosha L, Bagenda D et al. Response to antiretroviral therapy in HIV-infected Ugandan children exposed and not exposed to single-dose nevirapine at birth. J Acquir Immune Defic Syndr 2009; 52: 560-8.

19. Kilewo C, Karlsson K, Massawe A et al. Prevention of mother-to-child transmission of HIV-1 through breast-feeding by treating infants prophylactically with lamivudine in Dar es Salaam, Tanzania: the Mitra Study. J Acquir Immune Defic Syndr 2008; 48: $315-23$

20. Kilewo C, Karlsson K, Ngarina M et al. Prevention of mother-to-child transmission of HIV-1 through breastfeeding by treating mothers with triple antiretroviral therapy in Dar es Salaam. Tanzania: the Mitra Plus study. J Acquir Immune Defic Syndr 2009; 52: 406-16.

21. Rapid advice. Use of antiretroviral drugs for treating pregnant women and prevention HIV infections in infants. Genève: WHO, 2009.

22. HIV and infant feeding. Revised principles and recommendations. Rapid advice. Genève: WHO, 2009

23. Leshabari SC, Blystad A, Moland KM. Difficult choices: infant feeding experiences of HIV-positive mothers in northern Tanzania. SAHARA J 2007; 4: 544-55.

24. Bhandari N, Kabir AK, Salam MA. Mainstreaming nutrition into maternal and child health programmes: scaling up of exclusive breastfeeding. Matern Child Nutr 2008; 4 (suppl 1): 5-23.

25. Black RE, Morris SS, Bryce J. Where and why are 10 million children dying every year? Lancet 2003; 361: 2226-34

26. Mofenson LM. Prevention of breast milk transmission of HIV: the time is now. J Acquir Immune Defic Syndr 2009; 52: 305-8.

27. Towards universal access: scaling up priority HIV/ AIDS interventions in the health sector2008. Genève: WHO, Unicef, UNAIDS, 2008.

Manuskriptet ble mottatt 6.8. 2009 og godkjent 16.2. 2010. Medisinsk redaktør Siri Lunde. 